\title{
Rapid Urbanization-Its Impact on Sustainable Development: A Case Study of Udon Thani, Thailand
}

\author{
Thanadorn Phuttharak ${ }^{1} \&$ Apisak Dhiravisit ${ }^{2}$ \\ ${ }^{1}$ Development Science, Faculty of Humanities and Social Sciences, Khonkaen University, Thailand \\ ${ }^{2}$ Program in Faculty of Humanities and Social Sciences, KhonKaen University, Thailand \\ Correspondence: Thanadorn Phuttharak, Development Science, Faculty of Humanities and Social Sciences, \\ Khonkaen University, Thailand. E-mail: thanadorn4245@gmail.com
}

\author{
Received: May 27, 2014 Accepted: August 9, 2014 Online Published: October 30, 2014 \\ doi:10.5539/ass.v10n22p70 URL: http://dx.doi.org/10.5539/ass.v10n22p70
}

\begin{abstract}
This article focused on the pattern of land-use change based on urbanization and the impacts of land-use change on the local community in Udon Thani. Udon Thani was selected as a case study in this article because the rapid growth rate of the city was higher than that of other cities in decades. The study was conducted by satellite images analysis in order to compare the Udon Thani municipality and the suburban areas from 1989-2014. Group discussion was used with representatives from local communities, government sectors, and private sectors. Results revealed that the urbanization process has been settled based on both push and pull factors. Push factors consisted of the expectation of rural people in employment and income. Pull factors consisted of the expansion of the industrial sector, particularly in service and retail sectors, which affected the land-use change in the Central Business District (CBD) and surrounding communities. In addition, impacts of land-use changes on the community were found from several perspectives, including the economic, social, and environmental perspectives.
\end{abstract}

Keywords: urbanization, land-use changes, sustainable cities, Udon Thani

\section{Introduction}

Development approach in past decades primarily focused on the growth of economic which was centralized and generated by government and private sector based on capitalism. Infrastructural development would be priority that was applied on modernization process which focused only on quantitative development. Therefore, Western countries or developed countries got widely involve in generating patterns of development, and passed on their development patterns to the developing country. This phenomenon had a critical role in developing world society and the capitalism. So the developing country seems to run development pattern as the dependency development which was consequent on many problems in developing country.

Urbanization is a phenomenon that was introduced at the end of World War II. Urbanization has become a key factor that influences city development in major Asian cities. City development has developed from urbanization in various perspectives, especially economic and industrial perspectives, which were focused on. The development resulted in rapid economic and industrial growth, as the city was interested in many investment plans from national and international investors. However, the urbanization-based development also impacted the city. Urbanization currently is generating problems for the city. People from various places migrate to seek work and a better life in major cities more and more. Social and environmental problems also were discussed. City administrators cannot manage city problems that are impacting the city rapidly. Some call this phenomenon an "over urbanization."

The growth of urbanization caused a new type of production in the modern economy, which generated a pull factor for surplus labor in the agricultural sector and transformed cities into an industrial labor sector. Although urban development and economic growth in Asian countries were different from that in European countries or the United States in terms of the balance between the rural and urban populations and economic growth, the phenomenon of migration from rural to urban areas was still occurring due to high levels of productivity in the city, which was higher than in the rural areas. High levels of productivity became a pull factor, which resulted in an increasing population in the urban areas of Asia as well as within developing countries. In addition, poverty in 
the rural areas, the invasion of capitalism into rural areas, and rural living, which was infiltrated by consumerism, forced rural people to change their living patterns; for instance, the land was transferred to capitalists for industrial activities. These were the pull factors, which accelerated migration to the city. Though it was thought that the movement of people would lead to the development of the industrial sector, it actually caused numerous infrastructural, social, and environmental problems.

Urbanization and the growth of the modern city based on capitalism are important issues that city administrators must recognize, especially within developing countries, including Thailand. Adoption of the National Economic and Social Development Plan, which was based on Western countries' approach, affected a major change in the Thai economy and society. One of the most significant changes to Thailand's economy was a greater reliance upon industrial manufacturing as opposed to agricultural production. This made the country's urban areas change so rapidly that they were unable to control worrisome issues, such as the increase of the population, pollution, and so on. From 1960-1970, small-sized factories settled in Bangkok. This caused a massive migration from rural areas across the region, especially from the northeastern region. In 1970, the proportion of the population living in cities increased rapidly from $17 \%$ to $21 \%$ (Suthiprapa, Mithanon, Wattana, \& Taesrikut, 2008). In 1980, the growth rate of Bangkok, which was a type of a primate city, was higher than in Chiangmai, which was considered the second largest city in Thailand by more than 50 times. The city became over-urbanized similar to other cities in Southeast Asia, such as Jakarta, Manila, and Ho Chi Minh City, where the economic base and the city's infrastructure could not support the increase in population.

The Thai government later adopted a policy that focused on distributing growth among regional cities by applying the "growth poles" theory to develop the regional city as the core of economic growth. In Thailand, Chiang Mai and Khon Kaen were the provinces selected for development into regional cities in order to facilitate the growth of industry, as well as to reduce the congestion and pollution of the main city (i.e., primate cities, such as Bangkok). This policy was an attempt by the government to solve problems in the primate cities by distributing growth to other areas throughout the country. Although this policy was fine on paper, it led to the creation of new problems regarding the sustainability of secondary cities in both urban and rural areas, which reflects the inability of the state to impose regulations that make them more sustainable (Glassman \& Sneddon, 2003).

Udon Thani, which is located in northeastern Thailand, is a city that is growing and expanding rapidly. The advantage of Udon Thani's location has made it the hub of a region that is filled with regional conveniences, such as a transportation route that links the central and northeast region and international boundaries. Udon Thani has become the third highest economic growth area in the northeastern region. Though Udon Thani is continuously growing, it is facing more and more problems inherent to large cities, similar to other regional cities in Thailand where urban areas have expanded to agricultural areas and have linked with areas of other local municipalities. The city, then, is not only limit by administrative boundaries, but also covers the people who are living outside its administrative boundary but are still involved in urban activities, such as commuters who go to work in urban areas in the morning and return home in the evening to areas outside the city. This pattern of living reflects a city system in the modern world and an urban boundary that expands more to local areas. In addition, city expansion also has an unavoidably complex relationship with the locals in terms of economic, social, and environmental perspectives. The old-fashioned administrative boundary cannot cover all of the city system. The limitation of local government in operation, lack of development knowledge, and the lack of problem solving are also the conditions that result in inefficient urban development.

According to the development that focuses more on industrial activity and is a cause of rapid growth of the city, it is necessary to understand a concept of urbanization and sustainable development in 2 ways. The first one is to reach an understanding and study the urbanization. It is important to understand the connection between city systems including: 1) central city, 2) cities around the principle city plan, and 3) cities influenced by the central city. The study would be done by systematic approach to understand issues about impacts of city change in economic, social, and environmental perspectives. The second one is to understand the relationship and participation of city policy issues The city policy issues can be divided into 2 parts, which are 1) the structure of city policy issues including regulation, law, social norm, and organization; 2) agencies in policy issues including government (such as central government and local government), private sector (such as local entrepreneurs and large-size entrepreneurs), and public sector (such as community, academics, and NGOs).

The urbanization phenomenon in Udon Thani was driven by at least two factors: (1) the land-use change, and (2) the increase of population. Urbanization was a direct driver that caused changes in the ecosystem and led, in part, to climate change-the rapid change of the ecosystem that has been caused by humans who seek a particular lifestyle, especially following the industrial era. Humans have caused numerous changes to nature. The change 
in land use has had a direct influence on ecosystem processes (Nelson et al., 2006).

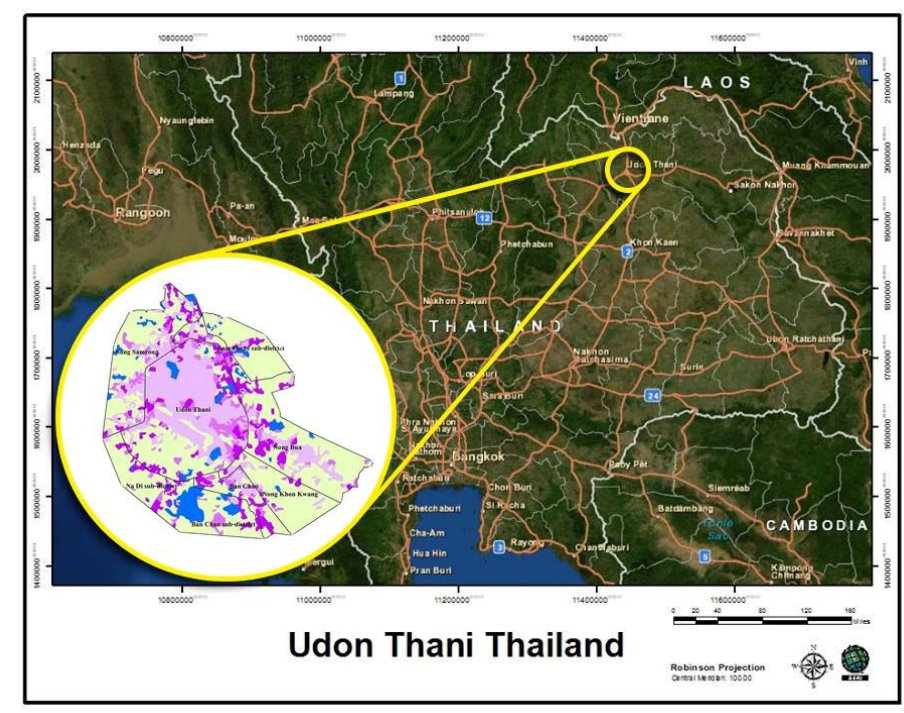

Figure 1. An expansion of regional cities in the northeastern region of Thailand

This study attempts to reveal patterns of urban development in Udon Thani city that are now expanding rapidly and investigates impacts of city expansion on local community. Patterns and impacts of city expansion will become key conditions that lead to issue guidelines of developing the sustainable city in the future. In addition, city stakeholders who engage in Udon Thani's development will be key informants to reveal impacts of how the city is expanding rapidly. At the core of sustainability is the need to pay attention to negotiating conflicts and to create a way to be a sustainable city. Where democracy is stunted, decisions and actions that weaken sustainability are more likely to occur. (Eckstein \& Throngmorton, 2003). In the agency, both local and urban areas are key factors that boost the development of Udon Thani through brainstorming and working together to regulate and issue suitable policies to bring sustainability to Udon Thani.

\section{Objectives}

Investigate patterns and impacts of city expansion to local community in Udon Thani city

\section{Theoretical Framework}

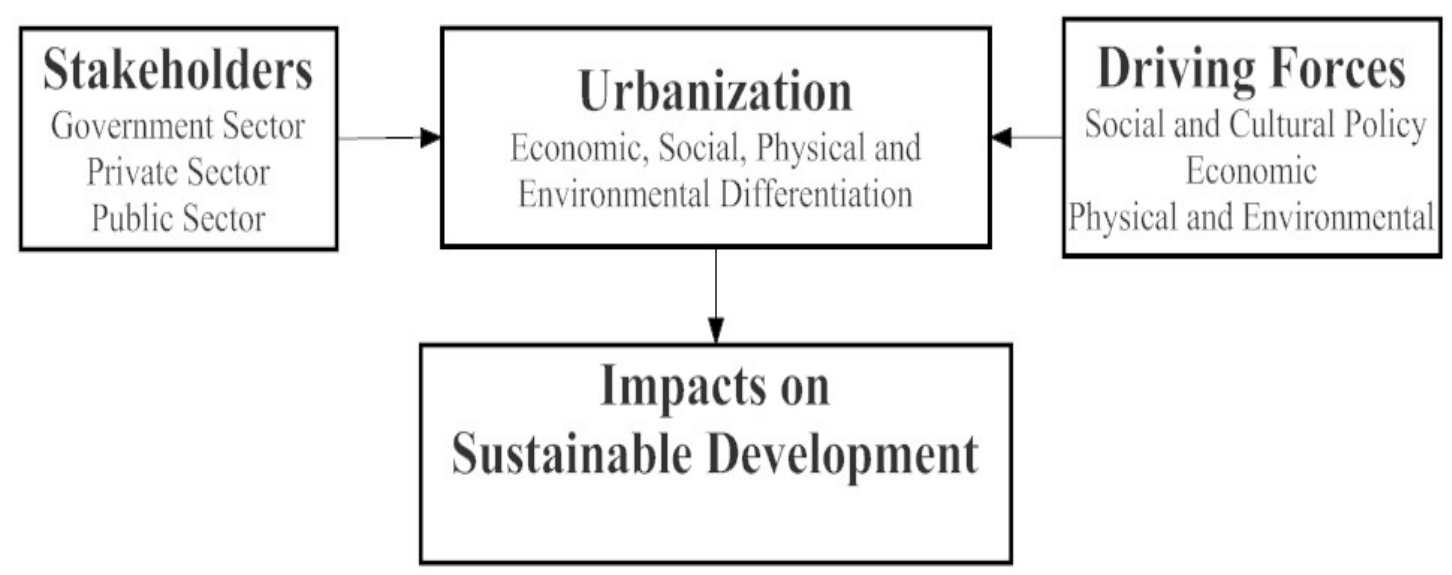

Figure 2. Theoretical Framework

The development of Udon Thani has introduced the long history of regional development, which has taken place because of the driving factors. Driving factors boosted the expansion of city scale and resulted in the strategic 
importance in the Indo-China region. The driving factors included: 1) strategic area of the Indo-China Region, 2) capitalist policy, and 3) the establishment of ASEAN Economic Community (AEC). These factors generated the rapid growth of the urban area of Udon Thani until the present. Urban areas are now expanding beyond the administrative boundary to suburban areas. The expansion of the city has been based on economic conduction and relates to the living patterns of people in Udon Thani. Stakeholders who are involved in urban development in Udon Thani included local government, the economic sector, and the public sector and have tried to manage and run the city by using sustainable development perspectives such as policy, socio-cultural, economic, and environmental perspectives. Finally, the development that took place in urban areas of Udon Thani affected the city. The effects that took place were both positive and negative and led to the management guideline for the sustainable city.

\section{Methods}

This study has been conducted in a qualitative approach to investigate patterns of city expansion and the impacts of city expansion and land-use changes on the community. Udon Thani was selected as a case study and included the Udon Thani municipality, the CBD, and suburban areas. Remote sensing and geographic information systems (GIS) were used to analyze patterns of city expansion to find the land-use changes within Udon Thani and suburban areas from 1989-2014. To find out the change of urban areas in Udon Thani, Satellite images from the LANSAT Satellite were introduced to identify the overview of land use within Udon Thani from 1984-2014. The identification was categorized into 4 groups including the Agricultural area, Scrub area, Urban area, and Water space. These 4 groups then would be analyzed with GIS data, economic data, social data, and population data to find the pattern of city expansion and the rate of area change between 1989-2014, which affected the city expansion in terms of geography, economics, social, and the environment.

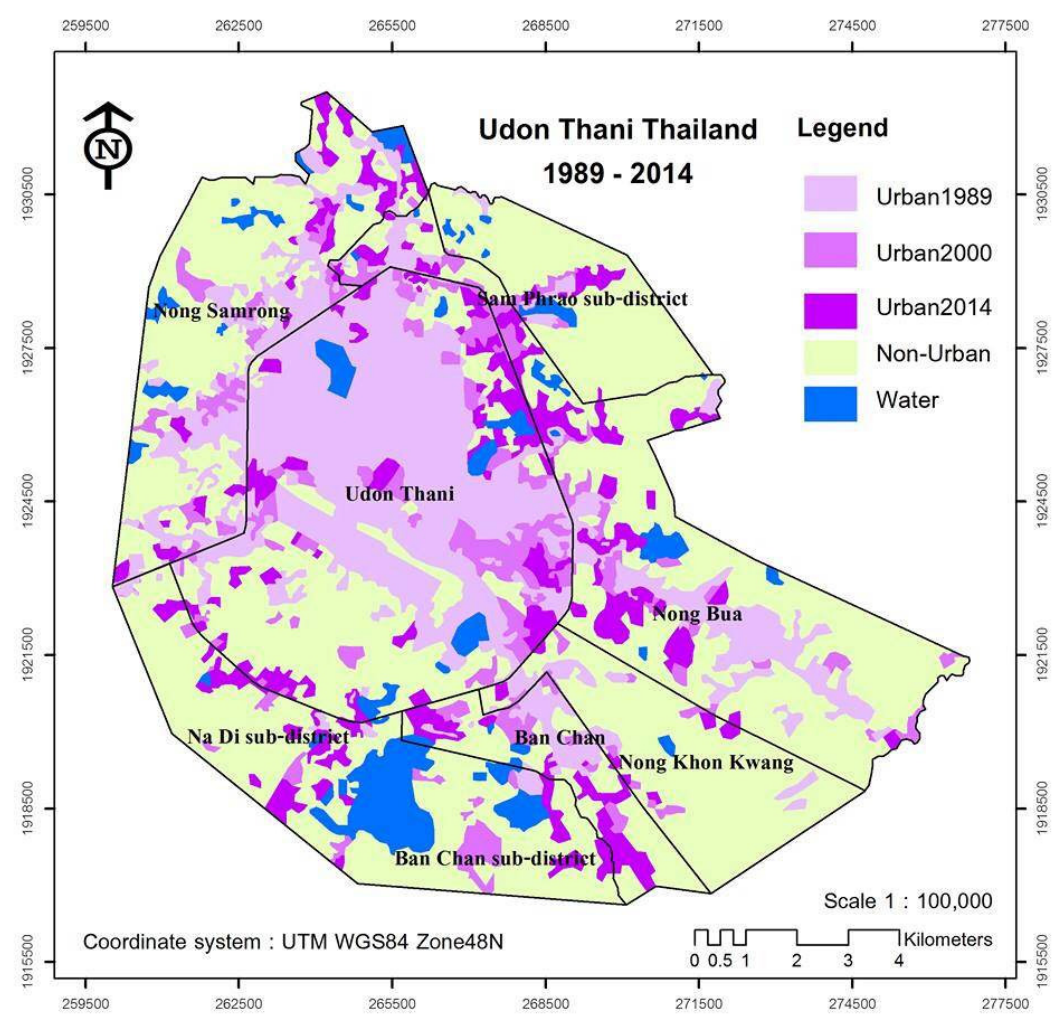

Figure 3. An overview of land-use change in Udon Thani from 1989-2014

City expansion in Udon Thani is another example which is based on Modernization theory. Modernization provided impacts on socio-economic change in local community where agricultural society has turned to be industrial or service society. This study tried to identify how did the expansion contribute to Udon Thani city in order to understand deeply details of the expansion pattern and the impacts of city expansion, in-depth interviews were used to collect data about the economic, social, and environment impacts, the participation of stakeholders, 
especially in the public sector in the city planning in the local government, and the limitation of city administration. Key informants included 12 persons from the local government, the economic sector, and the public sector. In addition, group discussion was also used in this study. According to city problems and the complexity of city administration, it was necessary to get information from various groups of stakeholders to find out problems in local community, and listen responds from the locals about problems and development guideline. 50 representatives were selected from various parts of city stakeholder included communities, government agencies, and private sectors to participate in group discussion to discover the impacts of city expansion and land-use changes on the local community. The conclusions, which were generated by stakeholders, were analyzed carefully in order to create suitable guidelines for sustainable city development. The gathered data were examined by a triangulation process; that is, the data were evaluated from the perspectives of its source, duration, and location to find similarities and differences. After examination, if the data went in the same direction, it could be concluded that the data were reliable. In contrast, if the data diverged, they would be examined by a triangulation process that compared the data from the first and the second source with data from the third source. If two of the three were similar, they were considered credible. After the data examination was finished, the data were categorized according to the issue studied. After that, the data were analyzed and compared for each issue to find the conclusion. A content analysis approach was used to interpret the data, and an inductive conclusion was created. Finally, description analysis was used to present the data by describing the facts our research discovered based on the theoretical framework.

\section{Results}

\subsection{The Patterns of City Expansion and the Land-use Changes}

According to Figure 2, the urban area in 1989 was 38.33 square kilometers. The urban area increased to 50.10 square kilometers in 2000 and up to 64.91 square kilometers in 2014. The agricultural area in 1989 was 105.11 square kilometers. The agricultural area decreased to 94.28 square kilometers in 2000 and was down to 82.94 square kilometers in 2014. The scrub area in 1989 was 9.13 square kilometers. The scrub area decreased to 7.87 square kilometers in 2000 and was down to 4.84 square kilometers in 2014 . The water space in 1989 was 8.46 square kilometers. The water space in 2000 was 8.76 square kilometers and was 8.33 square kilometers in 2014 . The figure shows that the urban area in the last couple decades increased while the agricultural area and scrub area decreased and turned into an urban area.

Table 1. Percentage of urban areas within local municipalities

\begin{tabular}{llll}
\hline & 1989 & 2000 & 2014 \\
\hline Udon Thani Municipality & 49.33 & 59.99 & 68.59 \\
Nong Samrong Municipality & 23.50 & 30.75 & 38.40 \\
Nong Bua Municipality & 17.62 & 23.34 & 36.16 \\
Ban Chan Municipality & 16.97 & 28.47 & 48.47 \\
Nong Khonkwang Municipality & 7.77 & 11.04 & 14.15 \\
Na Di and Ban Chan Sub-district & 2.16 & 7.86 & 17.56 \\
Sam Phrao Sub-district & 4.10 & 6.40 & 10.48 \\
\hline
\end{tabular}

The study found that in 1989, the urban area of Udon Thani municipality was $49.33 \%$ and increased to $59.99 \%$ in 2000 . The average growth rate was $0.969 \%$ each year. In addition, the urban area of Udon Thani municipality was $59.99 \%$ in 2000 and $68.59 \%$ in 2014 . The average growth rate was $0.614 \%$.

While considering municipalities in suburbans area from 1989-2000, it was found that the average growth rate of urban area increased $0.659 \%$ in Nong Samrong municipality, $0.520 \%$ in Nong Bua municipality, $1.045 \%$ in Ban Chan municipality, $0.297 \%$ in Nong Khonkwang municipality, $0.518 \%$ in $\mathrm{Na}$ Di and Ban Chan sub-district, and $0.209 \%$ in Sam Pharo sub-district. In addition, while considering municipalities in suburban area from 2000-2014, it was found that the average growth rate of urban area increased $0.546 \%$ in Nong Samrong municipality, $0.916 \%$ in Nong Bua municipality, $1.429 \%$ in Ban Chan municipality, $0.222 \%$ in Nong Khonkwang municipality, 0.592\% in Na Di and Ban Chan Sub-district, and 0.291\% in Sam Pharo sub-district.

According to the analysis of land-use change using GIS data, the growth rate of the urban area in Udon Thani municipality (CBD) has decreased, but the growth rate in the suburbs has increased. This situation of Udon Thani is similar to other cities in Southeast Asia, such as Bangkok, Manila, or Jakarta. 


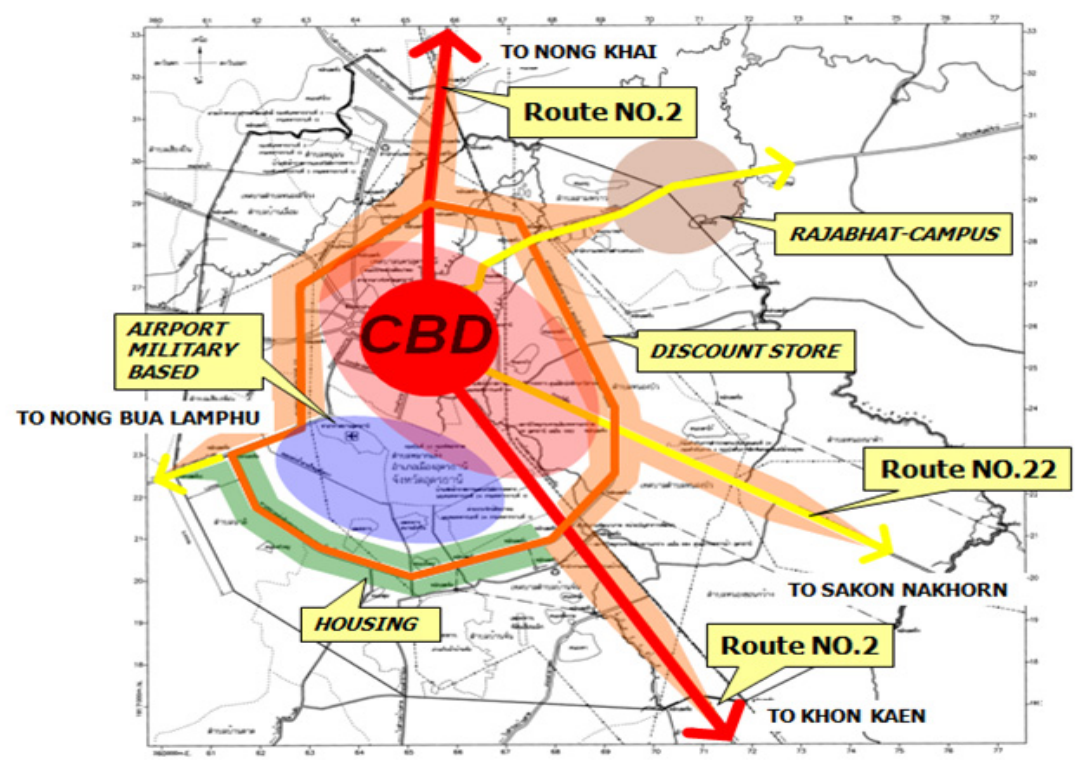

Figure 4. Direction of city growth (Prompakping et al., 2013)

The direction (red line) of Udon Thani growth related to the transportation routes, which include Highway No. 2 (Mittrapab Road) and Highway No. 22 (Nittayo Road: Udon Thani-Nakorn Phanom). Highway No. 2 passes through the Udon Thani municipality from the north to the south of the municipality (Nong Bua municipality and Ban Chan municipality), and Highway No. 22 passes through the east of the municipality. In addition, the Ring Road (east side) of Udon Thani is the location of major retail stores, the university, and a public park, which are key factors that attract the growth of the city in this direction. The west side of Ring Road is blocked by the airport and military area, so it is difficult to develop the city facilities in this direction.

The urbanization process of Udon Thani has developed on the Commercial Oriented, which is a conductor of city expansion similar to other major cities in Thailand. The expansion has occurred without a control base in the city planning, but the expansion is scattering all over the city (Upper Sprawl). This pattern of expansion affects the lack of infrastructure system in the community. Therefore, city planning is essential to guide the city expansion in the right direction and to solve city problems and move forward to be a sustainable city.

\subsection{The Impacts of City Expansion and the Land-use Changes on the Community}

The rapid growth of urban areas has affected the community, particularly from a land-use perspective. The effects are both positive and negative depending on the awareness and perception of the community. Planning of community protection is necessary in order to tackle city problems. Conclusions about the impact of rapid growth in urban areas are presented during the group discussion as follows.

\subsubsection{Economic Impact}

\section{1) Lands are used for commercial purposes in order to support economic growth.}

The study found that Udon Thani is located in a strategic area of the Indo-China region. The economy of the city has grown continually since the US army settled the Air Force base in 1965. In the present, the industrial sector, large retail enterprises, or even tourism attractions are developed rapidly to support the economic growth of Udon Thani. These conditions result in lands within Udon Thani that have been utilized for commercial purposes more than the demands of the business stakeholders. Moreover, the central and local government policies, which boost Udon Thani, become the center of the logistics in the region, which is also a driving force behind stimulating the economy, e.g., the second bus station or the study on the possibility of extending Udon Thani International Airport, which requires a lot of space to develop.

\section{2) An increase in land price}

Lands that are used intensively for commercial purposes and the development of infrastructure result in a higher land price. The study found that in 2004, the average price of land within Udon Thani city was 5-10 million Baht/acre, while in 2013 the average price was 20-40 million Baht/acre (Teerarattananukulchai, 2011). Land 
prices within Udon Thani have increased due to the following conditions: (1) Udon Thani is a center of a trade area along the border of Thailand-Laos. This results in a large number of locals and tourists that visit Udon Thani and create expenses within the city. (2) Groups of investors came to Udon Thani to purchase the land. This is another condition that causes an increase in land prices. Investors have come to buy and sell land, especially in the area near the UD Town, which is on the east side of Udon Thani. In addition, the transportation projects, which are issued by the government, are also a driving factor of land price increase, such as the interstate highway (the motorway) between Bang Pa-In, Saraburi, Nakorn Ratchasima and the high-speed train project route between Nakorn Ratchasima and Nong Khai. The price of the land near the project settlements has been steadily increasing.

\subsubsection{Social Impact}

\section{1) Decreasing residential area in the city}

The land-use changes, which increase the land price, also affects people in urban areas as well. The residential area has been decreased and changed into the business area. People who have low incomes can no longer occupy the land in urban areas, so they choose to live in the suburban areas where the price of land is cheaper. Moreover, some choose to sell their own lands in urban areas for a high price and move to purchase new land in the suburban area. The study also found that the popular area for housing in Udon Thani is in the east of the city located along the bypass where there is more and more construction of modern villages and facilities in suburban communities. The west side, however, is the least-developed area of the city due to the limitations of the military zone.

\section{2) Less agricultural areas}

Previously, Udon Thani municipality was filled with agricultural areas. Present use of land has caused a decrease in agricultural areas. The locals lost the land that they lived off of and were forced to work for the industrial or service sectors. This problem not only affects land owners but also some households that have rented land to live off of, which includes being able to collect natural resources for food. This problem might adversely affect the problem of food security in the urban area. However, food security issues might not affect urban areas directly, because those who live in urban areas easily access food as compared to those who live in rural areas. They easily access other food sources that are far away.

\section{3) Traffic problem}

The land-use changes also affect traffic conditions in urban area. Due to the change in the land to that of commercial purposes, people increasingly moving to urban area to conduct business. They primarily have their own vehicles and usually take their vehicles to urban area. Now Udon Thani is dealing with traffic problems, particularly in the morning as people come to the city on their morning commute. Traffic problems not only occur at the center of the city, but the problem also expands to the suburbs, especially in the east of the city where the residential area is. In addition, people in suburban areas reflect that this traffic problem is quite difficult to solve. The problem usually occurs in the morning and evening in urban areas. The bypass can no longer solve the traffic problem in Udon Thani. However, the relevant authorities may try to solve the problem; for instance, in Nong Bua municipality, the suburban area closest to an urban area is generating a road construction project to reduce the traffic problems through the construction of the second bypass road in 2017.

\subsubsection{Environmental Impact}

\section{1) Water pollution due to the fact that there is no drainage area or the drainage direction has changed}

Lots of houses, building construction sites, and land reclamation areas are major problems that can lead to environmental problems in Udon Thani. The problem can be analyzed in two cases: (1) the encroachment of construction into natural drainage areas, such as canals or rice fields. These areas are blocked by house or development project construction. The problem has been generated due to an increasing population in the urban area. People who are living in urban areas need to reclaim their own land to avoid flooding or unexpected situations and start constructing the residencies without any concern of negative impact on neighborhoods. The construction projects have blocked drainage direction, which has resulted in water pollution. The blocked water cannot drain away quickly and creates stinky sewage that impacts the community. It has also become the breeding grounds of insects such as mosquitoes.

2) Land reclamation has caused problems for households due to the land being reclaimed for house construction.

Those who reclaim the land usually make the land higher than others in order to avoid flood problems. However, 
the reclamation of land like this affects other households who had been living there before. The lands of others become an area for receiving rainfall and causes flooding. In addition, the reclamation has created a nuisance to the surrounding residents due to the falling of soil on the road, dust problems, or accidents while driving vehicles. Although the regulation for the reclamation of land is clearly generated, it does not solve the problem of land reclamation.

\section{3) Waste problem}

Waste disposal management has been operated by the Udon Thani municipality. The municipality serves the city by offering trash trucks to deliver the waste to the landfill located outside of the city. However, the land-use changes in urban and suburban areas led to negative effects on the local community. First, there is more waste than the disposal process can handle. The amount of waste is increasing due to the growth of the city and the high population density. The department that is responsible for waste management cannot eliminate the waste effectively, which later causes a pollution problem for the community. In addition, the amount of waste affects the community near the landfill. The smelly, putrid waste around the community and households that are close to the waste pit may be at risk of health problems and a lower quality of life. Moreover, the quality of surface water and groundwater near the waste pit is poor.

\section{4) Pollution from industrial sector}

According to the growth of Udon Thani, the growth leads to industrial investment in both urban and rural areas. One problem encountered in the industrial area concerns environment issues. The industrial sector produces a lot of waste each day, but the waste disposal management in industrial areas is quite limited, especially electronic waste, which is difficult to dispose of. This kind of waste will be delivered to another industrial site where there is an effective waste disposal system. A vast amount of electronic waste is produced each day, far too much for the disposal system to eliminate. Therefore, the agency responsible for waste delivery has to find another waste pit and wait to dispose of it later. Electronic waste is considered harmful to people's health. The preliminary solution instituted by the industrial sector is to install the waste disposal system in a major industrial factory. The output found that the disposal system runs smoothly, but there are some businesses that are not interested in the installation of the system. The local government should make the factories reduce their pollution.

\subsubsection{Policy Impact}

\section{1) Duplicated practices between municipalities and conflict in local areas}

Udon Thani is now a continuously growing base on the Commercial Oriented, which is a conductor of city expansion similar to other major cities in Thailand. The expansion has occurred without a control base on the city planning, and the expansion is scattering all over the city (Upper Sprawl). This expansion then affects the lack of infrastructure system in the community as well.

Related to the paragraph above, the city is facing problems similar to other regional cities in Thailand. Rapid expansion results in the uncontrolled expanding area not limited only by administrative boundary, but it also covers more than the administrative boundary to the way of life of people who live around the urban area. In addition, rapid expansion causes the duplication of operation between municipalities that are close to each other. When the operation of work duplicated, it would result in an inefficient development within areas and might cause conflicts between local areas. Therefore, it is important to identify operations of each municipality clearly and conform to other municipalities' plans to cooperate on the development plan.

\section{Conclusion and Discussion}

Impacts from city expansion affect the local community rapidly. Although some impacts provide positive results to the community, such as an economic boost, there are many impacts that provide some negative results, especially from social and environmental perspectives, which could be serious problems in the future. People in the city, both in urban areas and in suburban areas, have to defend against negative impacts that move to their residential area and cooperate to develop their homes with the help from the government sector and private sector to creative a sustainable development plan.

The phenomenon of urbanization in major cities in Thailand and Southeast Asia has continued to grow over for decades. The phenomenon has caused many problems, and spread to both the CBD and suburban areas. In Udon Thani city as well, people have to deal with more difficulties in their way of life because the city has grown very rapidly and has a higher complexity of management. Udon Thani city nowadays has been developed based on the Commercial Oriented, which is a conductor of city expansion. City expanding based on Commercial Oriented has occurred without a control by public agencies, but the expansion is scattering all over the city (Upper Sprawl). Private sector, with the support by government sector, becomes key agent to lead city expansion. 
This pattern of expansion then provides problems to local community in many ways. People in local community have to deal with social problem and environmental problem which they do not create even though they maybe get some positive effects on economic perspective. Local community has less chance to participate in city development. This development pattern results in the lack of cooperation between the locals, private sector, and government, and lead to an inefficiency of city development. Therefore, development has to be balanced with economic, social, and environmental factors. It is better to let every parts of city stakeholder participate in the city planning and city management in order to find the best guidelines for development.

It is challenging to find out the development guidelines for the city with public sector participation, and it is especially challenging for the local community to plan and issue city development guidelines. It is important to get the cooperation from every agency involved in the city to plan city guidelines, particularly the government and private sectors (public-private partnership, or PPP). Those related to issues including those from the economic, social, and environmental sectors should be balanced in bringing the community and city forward together. In addition, it is challenging to find the development guideline based on the concept of PPP. Empowering the public sector in the public space is also important. It is necessary to reach an understanding for the public sector to realize city development to create civil society and to promote the private sector to focus more on the CSR, which could lead to a process of sustainable city development in the future.

\section{Acknowledgements}

This research paper is funded through the Research University Grant from Khon Kaen University. Thank you to all of those on the educational committee in the doctor of philosophy program in development science, Faculty of Humanities and Social Sciences, Khon Kaen University, Research Group on Wellbeing and Sustainable Development (WeSD) for their helpful advice. Thank you to the government and private sectors in Udon Thani and particularly to the Udon Thani International Cooperation and Development office (UDICAD) for the data provided for this project.

\section{References}

Chaloemtiarana, T. (2009). Thailand: The politics of despotic paternalism. Bangkok: The Foundation for the Promotion of Social Science and Humanities Textbooks Project, Chulalongkorn University.

Eckstein, B., \& Throgmorton, J. A. (n. d.). Story and sustainability: Planning, practice, and possibility for American cities. London: MIT Press.

Frumkin, H., Frank, L., \& Jackson, R. (2004). Urban sprawl and public health: Designing, planning, and building for healthy communities. Washington: Island Press.

Giddens, A. (1984). The constitution of society: Outline of the theory structuration. Los Angeles: University of California Press.

Glassman, J., \& Sneddon, C. (2003). Chiang Mai and KhonKaen as growth poles: Regional industrial development in Thailand and its implications for urban sustainability. The Annals of the American Academy of Political and Social Science, 590, 93-115. http://dx.doi.org/10.1177/0002716203257075

Haemyuratham, A. (1985). History of interior UdonThani province. Bangkok: Amarin Printing.

Hugo, G. (2003, June). Urbanisation in Asia: An overview. Paper presented at Conference on African Migration, University of Adelaide, Australia.

Jone, G. W. (2002). Southeast Asia urbanization and the growth of mega-urban regions. Journal of Population Research, 2, 119-136. http://dx.doi.org/10.1007/BF03031973

Kamusoko, C., \& Aniya, M. (2007). Land use/cover change and landscape fragmentation analysis in the Bindura District, Zimbabwe. Land Degradation \& Development, 18(2), 221-233. http://dx.doi.org/10.1002/ldr.761

Mundia, C. N., \& Aniya, M. (2005). Analysis of land use/cover changes and urban expansion of Nairobi city using remote sensing and GIS. International Journal of Remote Sensing, 26(13), 93-115. http://dx.doi.org/10.1080/01431160500117865

Nelson et al. (2006). Anthropogenic drivers of ecosystem change: An overview Agronomy and Horticulture Department. University of Nebraska, Lincoln. Retrieved from http://digitalcommons.unl.edu/agronomy facpub/364

Permtunjit, K. (1993). Theories and concepts of urbanization. Bangkok: Creative Publishing Company Limited. 
Potsiou, C. (2010). Rapid urbanization and mega cities: The need for spatial information management. International Federation of Surveyors (FIG), 48. Retrieved from https://www.fig.net/pub/figpub/pub48/ figpub48.pdf

Prompakping et al. (2013). The Land-use Changes and Social Vulnerability of Udon Thani City. Khon Kaen Research Group on Wellbeing and Sustainable Development Khon Kaen University.

Rimmer, P. J., \& Dick, H. (2009). The city in Southeast Asia: Pattern, processes, and policy. Singapore: National University of Singapore Press.

Suthiprapa, J., Mithranon, P., Watana, P., \& Taesrikul, C. (2008). Bangkok-globalising the city of angels. In G. W. Jones, \& M. Douglass (Eds.), Mega-urban regions in Pacific Asia: Urban dynamics in a global era. Singapore: National University of Singapore Press.

Teerarattananukulchai, S. (Ed.). (2011). Journal of The Udon Thani Chamber of Commerce. Retrieved from http://udonechamber.com/home/journal-chamber/3053

Thavinpipatkul, D. (2008). Urbanization and social change in developing countries. Bangkok: Chulalongkorn University Press.

Van, T. T., \& Bao, H. D. X. (2008). A study on urban development through land surface temperature by using remote sensing: In case of Ho Chi Minh City. VNU Journal of Science, Earth Sciences, 24, 160-167. Retrieved from http://tapchi.vnu.edu.vn/e_3_08/b7.pdf

\section{Copyrights}

Copyright for this article is retained by the author(s), with first publication rights granted to the journal.

This is an open-access article distributed under the terms and conditions of the Creative Commons Attribution license (http://creativecommons.org/licenses/by/3.0/). 